\title{
Geração / Generation
}

https://doi.org/10.21814/uminho.ed.36.33

\section{Florbela Samagaio}

Escola Superior de Educação de Paula Frassinetti e Instituto de Sociologia, Faculdade de Letras da Universidade do Porto, Portugal 



\section{Geração}

O conceito de geração é vulgarmente utilizado no âmbito das ciências sociais e humanas assim como nas ciências naturais, designadamente pela Biologia. Trata-se de um conceito de grande amplitude e flexibilidade. A este associam-se várias ideias e entendimentos de acordo com o respetivo enfoque teórico (Attias-Donfout, 1988). Poder-se-á relacionar geração e idade biológica e o conceito poderá reportar ao período de sucessão entre descendentes em linha reta - avós, pais e netos -, assim como, noutra perspetiva, de análise demográfica, poderá aludir a três ciclos de vida e/ou três gerações. Poder-se-á referir a uma década de forte manifestação cultural, numa abordagem histórica e cultural, e, neste sentido, facilmente encontramos expressões como "a década de 1960" ou "the Sixties".

A noção de geração permite a introdução de uma relação dialética na análise entre a realidade e a significação da mesma, entre a geração e a consciência da geração, entre o fator tempo e a subjetividade do vivido, entre as dimensões individual e coletiva.

Independentemente do enfoque, encontramos como elemento comum a ideia de tempo. Na verdade, a história do mundo envolve discussões regulares e constantes entre o número de nascimentos e o número de mortes permeadas por sequências de acontecimentos tidas como unidades temporais de análise.

Definir o conceito de geração do ponto de vista sociológico suscita a resposta à seguinte questão: o que é que identifica um conjunto de pessoas como geração?

Existem várias dimensões na elaboração da resposta como, por exemplo, o ano de nascimento ou a década, o espaço e os traços culturais dominantes dum contexto histórico. Se atentarmos ao dicionário de língua portuguesa encontraremos, por exemplo, a seguinte definição "conjunto de pessoas da mesma época" (Moreno, 1971, p. 717). Esta designação comum traz consigo, por sua vez, a noção de "época". Efetivamente, o que significa uma época? 
Na perspetiva sociológica, e numa primeira aceção, poderemos referir que o conceito de geração se encontra balizado pelos trabalhos de autores como A. Comte (1798-1857), Antóine-Augustin Cournot (1801-1877), W. Dilthey (1833-1911), F.M. Ortéga Y Gasset (1883-1955) e Karl Mannheim (1893-1947). Embora com abordagens teóricas distintas, lançam as bases para 0 entendimento do conceito de geração ora numa conceção mais positivista, ora numa análise de natureza predominantemente sócio-histórica.

$\mathrm{Na}$ linha de pensamento de K. Mannheim, a geração não se constitui necessariamente a partir do momento do nascimento, ou quando o indivíduo se tornou jovem, adulto ou velho no mesmo tempo cronológico, mas sim a partir da possibilidade - dada a partir desse momento concreto - de poder participar dos mesmos acontecimentos, dos mesmos conteúdos de vida, por exemplo, e, sobretudo, de fazê-lo a partir dos mesmos padrões de consciência (1993), podendo participar das vivências coletivas.

No mesmo paradigma de compreensão, Adérito Sedas Nunes (1928-1991) explora o conceito de juventude não só como uma fase da vida, mas também como "uma constelação de meios sociais juvenis, culturalmente distintos" (Nunes, 1968, p. 85).

Assim poderemos entender melhor o conceito de geração na dimensão sociológica fazendo uma aproximação à noção de geração social desenvolvida por A. Sedas Nunes. Para este autor uma geração social só se determina mediante uma autorreferência a outras gerações relativamente às quais se vê como distinta. Neste sentido, embora possam ser relativamente coincidentes no tempo, geração social distingue-se de geração demográfica agregado estatístico de indivíduos cujas idades se situam dentro de certos limites. Geração social reporta a um conjunto de indivíduos cujas idades se concentram num grupo, embora com possíveis desvios individuais, dentro dum intervalo relativamente estreito cujos membros são detentores de um sentimento comum de se "encontrarem coletivamente em presença", na sociedade, de grupos distintos do seu pela idade, assim como pelas suas referências sociais, culturais e históricas (Nunes, 1968).

$\mathrm{Na}$ noção de geração entendida como fase de vida (infância, juventude, adultez, velhice) encontra-se subjacente a ideia de pluralidade de mundos sociais, ou seja, ao critério da idade acresce o da diversidade. Deste modo, e no que respeita à infância, segundo Mollo-Bouvier (1998) poderão existir várias infâncias dentro da categoria da infância. A criança vai transitando, nas suas várias infâncias, através de um percurso institucional que começa 
na creche, continua no jardim-de-infância e prolonga-se na escola. As infâncias são delimitadas por critérios administrativos e institucionais. Assim, a categorização social das idades procura responder a uma multiplicidade de exigências provenientes de diversos grupos de pressão: pais, trabalhadores sociais, educadores.

A ideia de diversidade na consideração do conceito de geração encontra-se patente nas abordagens no âmbito da sociologia da infância. Podemos entender geração como uma categoria estrutural relevante na análise dos processos de estratificação social e na construção das relações sociais (Qvortrup, 2000; Alanen, 2001; Mayall, 2002). Na verdade, o conceito de geração "impõe a consideração da complexidade dos fatores de estratificação social e a convergência sincrónica de todos eles; a geração não dilui os efeitos de classe, de género ou de raça na caracterização das posições sociais, mas conjuga-se com eles, numa relação que não é meramente aditiva nem complementar, antes se exerce na sua especificidade, ativando ou desativando parcialmente esses efeitos" (Sarmento, 2005, p. 363).

\section{Generation}

The concept of generation is commonly used in the social and human sciences as well as in the natural sciences, namely in biology. It is a concept of great breadth and flexibility.

This concept is associated with several ideas and theories according to the respective theoretical focus (Attias-Donfout, 1988). Generation and biological age may be related, and the concept may refer to the period of succession between straight descendants - grandparents, parents and grandchildren. In another perspective of demographic analysis, it may also refer to three life cycles and / or three generations. From a historical and cultural perspective, one could refer to a decade of intense cultural manifestation, such as "the sixties", as a generation.

The notion of generation allows the introduction of a dialectical relationship in the analysis between reality and its meaning, between generation and the awareness of generation, between the time factor and the subjectivity of the lived experience, between the individual and collective dimensions.

Regardless of the focus, we shall find the idea of time as a common element. In fact, world history involves regular and constant discussions between the 
number of births and the number of deaths punctuated by sequences of events considered as temporal units of analysis.

Defining the concept of generation from a sociological point of view requires the answer to the following question: What identifies a group of people as a generation? There are several dimensions in the elaboration of the answer, for example, the year of birth or the decade, the space and the dominant cultural features of a historical context.

From a sociological perspective, and in a primary sense, we can say that the concept of generation is based on the works of authors such as A. Comte (1798-1857), Antóine-Augustin Cournot (1801-1877), W. Dilthey (1833-1911), F.M. Ortéga Y Gasset (1883-1955) and Karl Mannheim (1893-1947). Although their theoretical approaches are different, they lay the foundation for understanding the concept of generation, sometimes in a more positivist conception, sometimes in an analysis of a predominantly socio-historical nature.

In K. Mannheim's thinking, generation does not necessarily constitute itself from the moment of birth, or when the individual became young, adult or old at the same chronological time, but rather from the possibility given from that concrete moment - of being able to participate in the same events, the same contexts of life, for example, and, above all, to do so from the same standards of conscience (1993), so being able to participate in collective experiences.

In the same paradigm of understanding, Adérito Sedas Nunes (1928-1991) explores the concept of youth not only as a phase of life but also as "a constellation of youthful, culturally distinct social media” (Nunes, 1968, p. 85).

In this way, we can better understand the concept of generation in the sociological dimension by approaching the notion of social generation developed by A. Sedas Nunes. For this author, a social generation is determined only by self-reference to other generations from which it is seen as distinct. In this sense, although they may be relatively coincident in time, social generation is distinguished from demographic generation - a statistical aggregate of individuals whose ages are within certain limits. Social generation refers to a group of individuals whose ages are concentrated in a group, although with possible individual deviations, within a relatively narrow range whose members have a common feeling of "being collectively present" in 
society, from different groups of the society. It is defined by age, as well as by its social, cultural and historical references (Nunes, 1968).

In the notion of generation understood as a life stage (childhood, youth, adulthood, old age), the idea of a plurality of social worlds is underlying. That means the age criterion is added to that of diversity. Thus, and with reference to childhood, there may be several childhoods within the category of childhood. The child moves, in his various childhoods, through an institutional path that begins in the nursery, and continues through kindergarten and school. Childhoods are demarcated by administrative and institutional criteria. Thus, the social categorization of ages responds to a multiplicity of demands from different pressure groups: parents, social workers, and educators.

The idea of diversity in the consideration of the concept of generation is evident in the approaches in the field of childhood sociology. We can understand generation as a relevant structural category in the analysis of social stratification processes and in the construction of social relations. In fact, the concept of generation "imposes the consideration of the complexity of the factors of social stratification and the synchronous convergence of all of them; generation does not dilute the effects of class, gender or race in the characterization of social positions, but is combined with them, in a relationship that is not merely additive or complementary, but is exercised in its specificity, partially enabling or disabling these effects" (Sarmento, 2005, p. 363).

\section{Referências / References}

Attias-Donfut, C. (1988). Sociologie des générations. L'empreinte du temps. Paris: PUF.

Manheim, K. (1993). El problema de las generaciones [tradução: Ignacio Sánchez de la Yncera], REIS - Revista Española de Investigaciones Sociológicas, 62, 193-242.

Nunes, A. S. (1968). Sociologia e Ideologia do desenvolvimento. Lisboa: Moraes Editores.

Sarmento, M. J. (2005). Gerações e Alteridade. Interrogações a partir da Sociologia da Infância. Educ. Soc., Campinas, 26 (91), 361-378. 